\title{
Quality and botanical composition of cattle diets under rotational and continuous grazing treatments
}

\author{
JOHN W. WALKER, RODNEY K. HEITSCHMIDT, ELINO A. DE MORAES, MERWYN M. KOTHMANN, AND STEVE L. DOWHOWER
}

Abstract

Proponents of rotational graxing claim that individual animal performance in a properly managed rotational grazing (RG) treatment will be equal to or greater than that in other, less intensively managed treatments even when rate of stocking in the RG treatment is much greater. The objective of this study was to examine the effect of a heavily stocked RG treatment, at 2 stock densities, on quality and botanical composition of cattle diets. The control treatment was a moderately stocked, continuously grazed pasture. Diets were collected from all treatments on 8 dates over a 22-month period using esophageally fistulated steers. Oniy minor differences occurred among treatments in dietary crude protein (CP), organic matter digestibility (OMD), and botanical composition. Diet quality and species composition of diets were closely correlated with quality and availability of live herbage, which varied more among trials than among treatments. Quality and composition of diets collected during the first and last day of grazing in the RG paddocks were not different. These data support the hypothesis that installing rotational grazing at a high stocking rate does not lower diet quality and would not be expected to be a factor affecting individual animal performance.

Key Words: crude protein, organic matter digestibility, stocking rate, graxing system

Interest in rotational grazing systems (RG) has increased dramatically in the U.S. during the past 10 years. Of particular interest has been the claim that proper implementation of a multi-paddock RG system will improve rangeland productivity in terms of livestock carrying capacity (Savory and Parsons 1980). This increase in carrying capacity has been attributed generally to substantial increases in quantity and quality of forage produced as a result of the positive effects of the physical impact of the grazing herd on the range ecosystem relative to plant growth and ecological succession. This claim was made, however, in the absence of any supportive scientific data. Thus, in 1981 studies were initiated to evaluate the effects of a RG treatment on quantity and quality of herbage produced and consumed, harvest efficiency, animal behavior, watershed condition, livestock performance (cow/calf), and economic profits. Six previous papers have quantified the effects of 2 livestock densities in a RG treatment on quantity and quality of forage produced (Heitschmidt et al. 1987a, 1987b, 1987c), watershed condition (Pluhar et al. 1987), animal behavior (Walker et al. 1988), and density of cattle trails (Walker and Heitschmidt 1986). This paper reports on the effects of this same RG treatment on quality and botanical composition of cattle diets. Our basic

\footnotetext{
At the time of this research authors were Tom Slick Fellow, Range Seience Department, Texas A\&M University, College Station, 77843; professor Texas Agr. Exp. Sta., Vernon, 76384; graduate research assistant and professor, Range Science Department, Texas A\&M Unniversity, College Station, and research associate, Texas Agr. Exp. Sta., Vernon. Walker presently is range scientist, USDA/ARS Sheep Experiment Station, HC 62 Box 2010, Dubois, Ida. 83423.

Appreciation is extended to the Swen $\mathbf{R}$. Swenson Cattle Co. for providing the land, livestock, and facilities for this study and the Texas Experimental Ranch Committee and the E. Paul and Helen Buck Waggoner Foundation for providing financial assistance.

Report is published with the approval of the Director, Texas Agr. Exp. Sta. as TA 23837.

Manuscript accepted 1 December 1988.
}

hypothesis was that diet quality would be less in the heavily stocked RG treatment than a moderately stocked continuously grazed (MC) treatment as a result of differences between treatments in grazing pressure.

\section{Methods}

\section{Study Site}

The study was conducted on the Texas Experimental Ranch located on the eastern edge of the Rolling Plains $\left(99^{\circ} 14^{\prime} \mathrm{W}, 33^{\circ} 20^{\prime}\right.$ N). Climate is continental, semiarid. Average annual precipitation is $682 \mathrm{~mm}$. Precipitation is bimodally distributed with peaks occurring in May $(96 \mathrm{~mm})$ and September $(188 \mathrm{~mm})$. Average maximum daily temperatures range from $11.4^{\circ} \mathrm{C}$ in January to $35.8^{\circ} \mathrm{C}$ in July. Average minimum daily temperatures range from $-2.4^{\circ} \mathrm{C}$ in January to $22.0^{\circ} \mathrm{C}$ in July.

Soils at the ranch are mostly deep, well-drained clays and clay loams. Dominant range sites are clay loam, clayey upland, and clay slopes. Herbaceous vegetation is a mixture of short- and midgrasses. Dominant shortgrasses are buffalograss [Buchloe dactyloides (Nutt.) Engelm.] and common curlymesquite [Hilaria berlangeri (Steud.) Nash], both warm-season perennials. Dominant midgrasses are sideoats grama [Bouteloua curtipendula (Michx.) Torr.], a warm-season perennial, and Texas wintergrass (Stipa leucotricha Trin. and Rupr.), a cool-season perennial. The dominant annual grass is Japanese brome (Bromusjaponicus Thumb.). The treatment pastures support a light stand of honey mesquite (Prosopis glandulosa Torr. var. glandulosa). For a more detailed description of the climate, soils, range sites, and vegetation at the study site, see Heitschmidt et al. (1985).

\section{Treatment}

The 465-ha, cell designed RG treatment was established in March 1981. The MC treatment was a single, 248-ha pasture established in 1960. Both treatments were stocked with mature Angus $X$ Hereford crossbred cows and all treatment pastures had a range condition classification of good. Rate of stocking in the RG treatment was a near constant $3.7 \mathrm{ha} / \mathrm{cow} / \mathrm{yr}$ until June 1984 when rate of stocking was reduced to $5.2 \mathrm{ha} / \mathrm{cow} / \mathrm{yr}$ because of drought. Rate of stocking in the MC treatment was a constant 6.2 ha/cow/yr.

The RG treatment initially consisted of 14 paddocks that averaged 33 ha in size. In March 1982 one 30-ha paddock was subdivided into three 10-ha paddocks. Data for this study were collected in these three 10-ha paddocks and 2 adjacent 27-ha paddocks to evaluate the effects of number of paddocks (stock density). To maintain equal rates of stocking, length of each grazing period was adjusted by an amount proportional to pasture size. Length of graze in the flexible rotation schedule ranged from 2 to 5 days in the 30-ha paddocks and 18 hours to 2 days in the 10-ha paddocks. Length of rest between grazing periods ranged from about 30 to 65 days depending upon vegetation growth rates and the nutrient requirements of the cows. The 30-ha paddocks are referred to hereafter as the RG-14 treatment and the 10-ha paddocks are hereafter referred to as the RG-42 treatment because livestock densities in the RG-14 and RG-42 paddocks approximated those 
of 14 and 42-paddock RG systems, respectively. For a more detailed description of the treatments, see Heitschmidt et al. (1987a, 1987b, 1987c).

\section{Sampling Procedures}

Diet samples were collected in both treatments during 8 seasonal trials between October 1982 and August 1984. Trials were conducted during normal rotation schedules. Each trial began when cattle entered the first RG paddock and continued until they departed the last RG paddock. Length of trial ranged from 6 (30-day rest) to 15 (65-day rest) days. Diets were collected during the first and last grazing bout in all RG paddocks and at the mid-point when length of grazing period exceeded 2 days. Diets in the MC treatment were collected approximately every other day.

Diet samples were collected from 3 to 5 esophageally fistulated, Jersey $\times$ Angus/Hereford crossbred steers per treatment. Steer weights increased from 200 to $450 \mathrm{~kg}$ from the beginning to the end of the study. The steers were combined with the 2 treatment herds approximately 1 week prior to the beginning of each trial. Esophageal extrusa samples were collected without fasting and in the same area as the cow herd was grazing during a 30- to 60-min sample period. Regurgitated contribution to the extrusa samples was manually removed and discarded.

Following each sample period, each diet sample was thoroughly mixed by hand and frozen. Samples were then lyophilized and a subsample removed for botanical analysis. The remainder was ground through a $20.3-\mathrm{cm}$ Wiley mill to pass a $1-\mathrm{mm}$ sieve. Nutrient analyses included determination for percentage crude protein (CP) and organic matter digestibility (OMD). Crude protein was determined by the micro-Kjeldahl method (A.O.A.C. 1970). Organic matter digestibility was estimated in vitro by a 2-stage procedure of incubating the sample in strained rumen fluid for 48 hours, followed by neutral detergent extraction (Van Soest et al. 1987). In vitro estimates were corrected using the ratio of in vitro/in vivo digestibilities of standard forages of known digestibility determined in a feeding trial. Botanical composition of extrusa fragments was determined by species using the microscopic frequency technique as described by Kothmann (1968). Species/species groups, hereafter referred to as species, were Texas wintergrass (Stle), annual grasses (Angr), sideoats grama (Bocu), other warmseason grasses (Wsgr), and forbs (Forb). For a more detailed description of sampling procedures, see de Moraes (1985).

\section{Statistical Analyais}

Percentage CP and OMD were statistically analyzed using repeated measurements least squares analysis of variance with grazing treatment as the main plot and trial as a sub-plot. Botanical composition of the diets was analyzed in a similar manner except plant species were sub-plots and trial was a sub-sub-plot (Engeman et al. 1986). Data from the RG-1 4 treatment were further analyzed to determine if CP or OMD differed between the initial and final day of grazing in a paddock using a within paddock split-plot analysis. Error variance for statistical tests was based on the 2 paddocks in the RG-14 treatment and 3 paddocks in the RG-42 treatment. If the covariance matrix of the repeated measures did
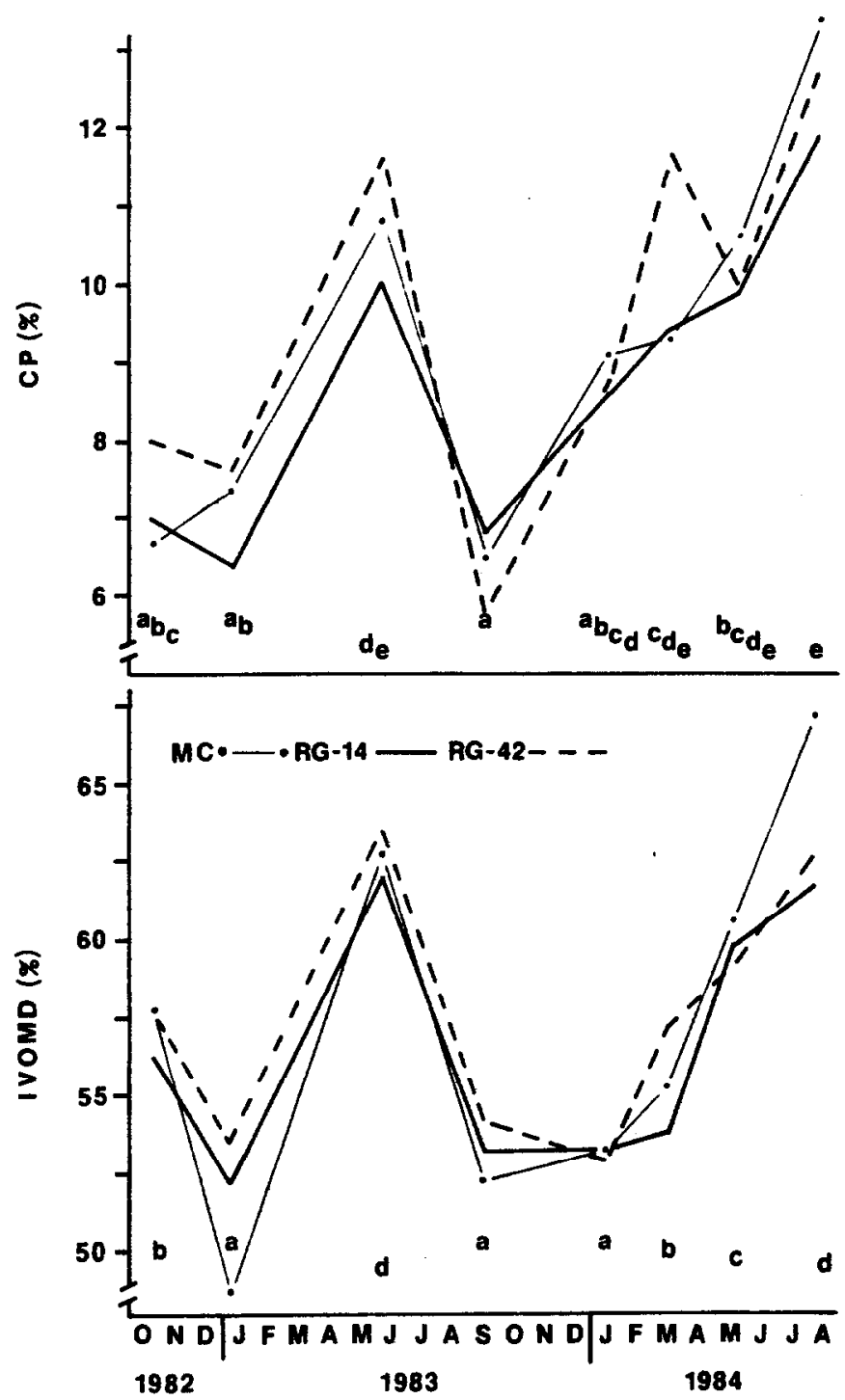

Fig. 1. Percentage $C P$ and $O M D$ of cattle diets across 8 trials. Meansfor trials with same letter are significantly different at $\mathrm{P}=0.05$.

not satisfy the Huynh-Feldt condition, the probability level of the associated F-ratio was based on the Box correction for degrees of freedom (Huynh and Feldt 1976). Protected least significant differences were used for mean separation. The paddocks in the RG treatment are not independent (Walker and Richardson 1986) and any inferences made from this grazing treatment case study to a larger population are based on the authors' experience and supporting literature.

Relationships between diet composition and herbage parameters were described using correlations. Herbage data were pub-

Table 1. Correlation coeficients between pereentage CP and OMD in cattie diets and varios herbaceous standing crop parameters.

\begin{tabular}{|c|c|c|c|c|c|c|c|c|c|}
\hline \multirow{2}{*}{$\begin{array}{l}\text { Diet Com- } \\
\text { ponent }\end{array}$} & \multicolumn{3}{|c|}{$\begin{array}{c}\text { Live Standing Crop } \\
(\mathbf{k g} / \mathbf{h a})\end{array}$} & \multicolumn{3}{|c|}{$\begin{array}{c}\text { Total Standing Crop } \\
(\mathbf{k g} / \mathbf{h a})\end{array}$} & \multirow{2}{*}{$\begin{array}{c}\text { Live/ Dead } \\
\text { Ratio }\end{array}$} & \multicolumn{2}{|c|}{ Grazing Pressure } \\
\hline & Biomass & $\mathbf{C P}$ & OMD & Biomass & CP & OMD & & Live & Total \\
\hline \multicolumn{10}{|c|}{ Correlation Coefficient (r) } \\
\hline OMD & $0.63 * *$ & $0.67 * *$ & $0.64 * *$ & 0.18 & $0.45^{* *}$ & 0.27 & $0.68^{* *}$ & $-0.31^{*}$ & -0.07 \\
\hline
\end{tabular}

****Significant at the 0.05 and 0.01 levels, respectively. 
lished previously (Heitschmidt et al. 1987a, 1987b, 1987c). Although the herbage data were collected on one range site and do not represent the entire pasture, we believe the data are representative of general pasture differences.

\section{Results}

Percentage $C P$ in the diet was affected by grazing treatment $(P=$ $0.02)$ and trial $(P<0.001)$, but not by their interaction $(P>0.38)$. Mean percentage $C P$ of diets was greater in the RG-42 (9.39\%) and MC (9.23\%) treatments than the RG-14 (8.62\%) treatment. Analysis of CP for each trial separately showed that the only differences $(P<0.10)$ were higher percentages in the RG-42 compared to the RG-14 treatments during the January 1983 and March 1984 trials. The small average difference among treatments (i.e., $<1 \%$ ) and the small number of differences due to treatment when the data were analyzed in individual trials indicated that the effect of grazing treatment on dietary $\mathrm{CP}$ was of minor practical importance. The affect of trial on percentage CP (Fig. 1) followed normal seasonal trends in forage quality (Heitschmidt et al. 1987b, 1987c). Seasonally, diet CP ranged from $6.2 \%$ in September 1983 to $12.5 \%$ in August 1984. Percentage OMD of diets was affected only by the main effect of trial $(P<0.001)$ which followed seasonal trends similar to CP, except that OMD remained low during January 1984 (Fig. 1). OMD ranged from 53.1\% in January 1983 and 1984 to $63.1 \%$ in August 1984 . We believe these data provide no evidence to indicate that increasing the number of paddocks in the rotational grazing treatment from 14 to $\mathbf{4 2}$ caused an increase in diet quality to occur. There were no significant differences in either percentage CP $(P>0.24)$ or OMD $(P>0.82)$ between diets collected at the beginning and end of each grazing period within the RG treatment paddocks.

Botanical composition of the diets (Fig. 2) was affected only by species $(P<0.001)$ and trial $(P<0.001)$. Seasonal variations in species composition of diets were related to changes in live standing crop among the different species caused by temporal differences in phenological development among species (Heitschmidt et al. 1987a). The similarity among treatments in botanical composition of diets presumably explains the similarity among treatments in diet quality.

Because estimated live standing crops on clay loam range sites in these same paddocks/pastures were not affected by treatment (Heitschmidt et al. 1987a, 1987c), it is not surprising that the grazing treatments did not affect either the botanical or nutrient composition of the cattle diets. Correlations of percentage $\mathrm{CP}$ and $O M D$ in diets from all trials with various herbage standing crop parameters indicated diet quality was more closely related to the absolute and relative (live/dead) amounts of live herbage available than to either total amount of herbage available or grazing pressure (Table 1). This indicates that diet quality varied seasonally as a function primarily of availability of live herbage rather than availability of total herbage or grazing pressure.

Nutrient and botanical composition of diets were generally not correlated to the amount of live herbage available within a trial. This indicates that either differences in standing crop biomass and structure among grazing treatments and pastures were insufficient to impede diet selection or that the relationship was nonlinear. We believe, however, that no relationship existed based on visual assessment of the plotted diet composition data against live standing crop estimates. The absence of a relationship between diet and standing crop is in agreement with the lack of significant differences among treatments in the dietary parameters discussed above, as well as a lack of differences among treatments in live standing crop biomass (Heitschmidt et al. 1987a, 1987c).

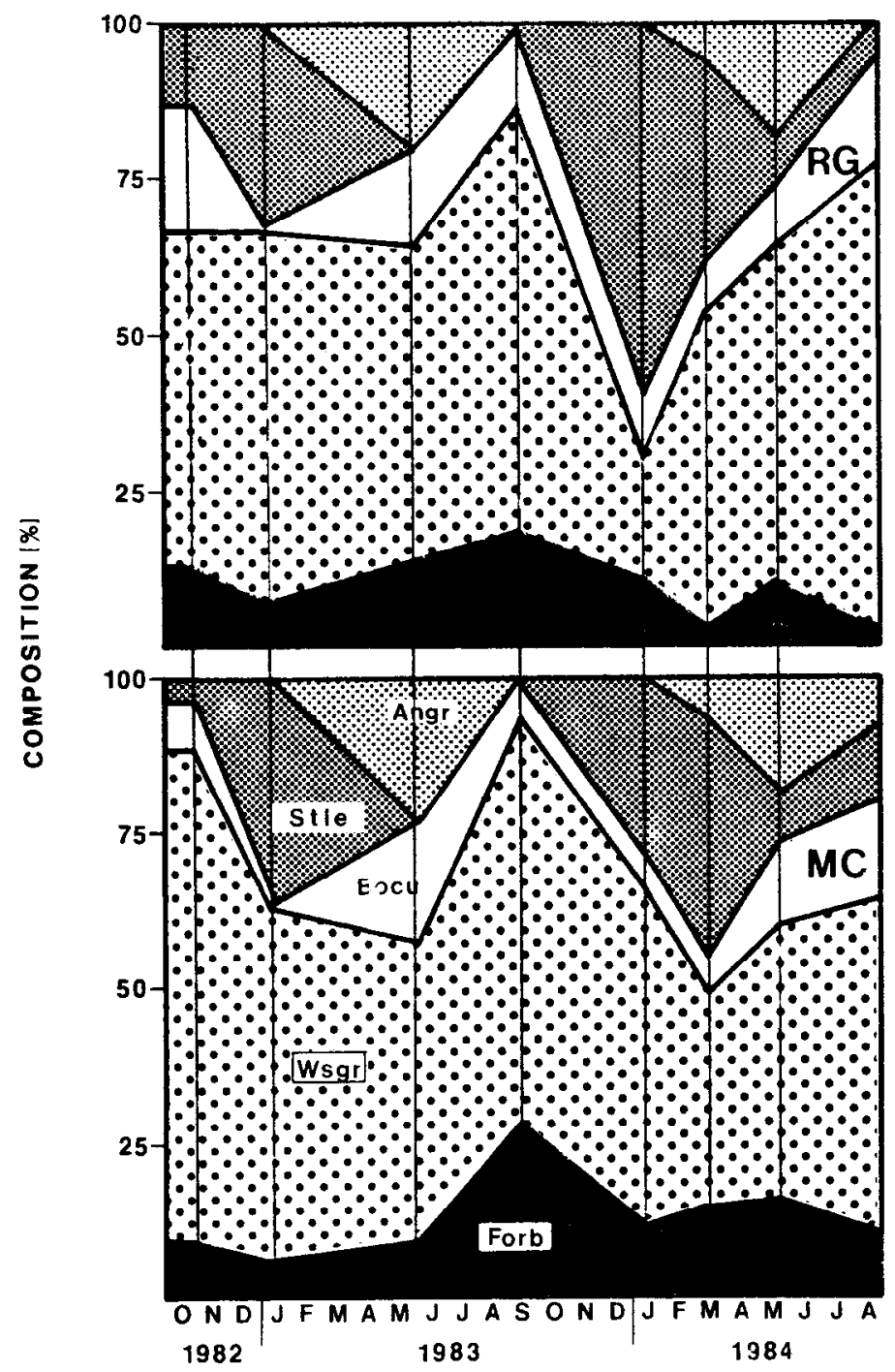

Fig. 2. Species composition (\%) of cattle diets across 8 trials in rotational (RG) and continuous (MC) grazing treatments. See text (Sampling Procedures) for species identification codes.

\section{Discussion}

Based on the results of this study, we reject our hypothesis that diet quality would be greater in the MC than RG treatment. These data indicate that differences in grazing pressure caused by variations in stock density did not dramatically affect diet selection. This conclusion is supportive of our previous findings that showed preference for various plant communities was not affected by these grazing treatments (Walker et al. 1988).

The results from this study are also supported generally by the findings of others relative to the effects of rapid rotational grazing systems on diet quality and botanical composition. Taylor et al. (1980) reported that both botanical and chemical composition of diets were similar in a 7-paddock (7-day graze) rotational grazing system and a 4-pasture, 3-herd deferred rotation grazing system in central Texas. In west Texas, Pitts and Bryant (1987) found no difference in nutrient composition of diets of fistulated steers grazing a 16-paddock rotational grazing system compared to continuous grazing. Differences in botanical composition of diets between the 2 grazing treatments were attributed to differences in the floristic composition of these pastures. New Mexico researchers also 
found differences in botanical composition of cattle diets in rotation compared to continuous grazing systems (Long et al. 1982) but they were not able to separate treatment effects from pasture effects. Sharrow (1983) suggested that differences in sheep performance (both positive and negative) between rotational and continuous grazing treatments on annual hill pastures in Oregon were caused by differences between treatments in diet quality. However, he also attributed these dietary differences to differences between treatments in available herbage.

The similarity we observed in quality and botanical composition of diets between the first and last day of grazing period in the rotationally grazed treatments is also in agreement with most other published research (Taylor et al. 1980, Kirby and Parman 1986, Pitts and Bryant 1987), although Ralphs et al. (1986) reported that significant changes did occur in both sheep and cattle diets during 3-day grazing periods in a simulated rotational grazing treatment stocked at various levels. The magnitude of change was directly related to the diversity of plant species available in that a shift in diet composition occurred only when alternative species were available for grazing following depletion of the preferred species.

The results from these studies tend to sustain Arnold and Dudzinski's (1978) contention that although grazing behavior may vary among grazing treatments in intensive pasture systems as a function of differences in forage yield and presentation, it may not vary in response to differences in the forage resource in extensive grazing environments. The absences of differences in diets among grazing treatments in this study may also have been caused by a lack of large differences in palatability among the major forage species in the pastures. This would have important implications regarding the long-term effect of various grazing management practices on species composition of pastures.

Lastly, caution should be exercised in the interpretation of these data because diet quality is but one aspect of livestock production. Still, the results do show that diet quality was maintained in the heavily stocked RG treatment at a level near that in the moderately stocked continuously grazed treatment. They do not indicate, however, that diet quality was enhanced by the RG treatment regardless of level of sub-division. Thus, based on the results of this study, we simply conclude that our management tactics, relative to rate of rotation of the grazing herd (length of graze/rest in each paddock) prevented a serious decline in diet quality within grazing trials.

\section{Literature Cited}

A.O.A.C. 1970. Official methods of analysis (11th Ed). Association of Official Analytical Chemist. Washington, D.C.

Arnold, G.W., and M.L. Dudzinskj. 1978. Development in animal and veterinary sciences, 2 . Ethology of free-ranging domestic animals. Elsevier Scientific Publ. Co., New York.
Engeman, R.M., D.E. Plamquist, and L.L. McDonald. 1986. The use of repeated measurement designs in field studies. p. 59-66. In: Proc. Statistical Analyses and Modeling of Grazing Systems Symp. C.D. Bonham, S.S. Coleman, C.E. Lewis, and G.W. Tanner (eds.) Soc. Range Manage. Denver, Colo.

Heitschmidt, R.K., S.L. Dowhower, R.A. Gordon, and D.L. Price. 1985. Response of vegetation to livestock grazing at the Texas Experimental Ranch. Tex. Agr. Exp. Sta. B-1515.

Heitschmidt, R.K., S.L. Dowhower, and J.W. Walker. 1987a. 14 vs. 42-paddock rotational grazing: aboveground biomass dynamics, forage production, and harvest efficiency. J. Range Manage. 40:216-223.

Heitschmidt, R.K., S.L. Dowhower, and J.W. Walker. 1987b. 14- vs. 42-paddock rotational grazing: forage quality. J. Range Manage. 40:315-317.

Heitschmidt, R.K., S.L. Dowhower, and J.W. Walker. 1987c. Some effects of a rotational grazing treatment on quantity and quality of available forage and amount of ground litter. J. Range Manage. 40:318-321.

Huynh, H., and L.S. Feldt. 1976. Estimation of the Box correction for degrees of freedom from sample data in the randomized block and split plot designs. J. Educ. Stat. 1:69-82.

Kirby, D.R., and M. Parman. 1986. Botanical composition and diet quality of cattle under a short duration grazing system. J. Range Manage. 39:509-512.

Kothmann, M.M. 1968. The botanical composition and nutrient content of the diet of sheep grazing on poor condition pasture compared to good condition pasture. Ph.D. Diss., Texas A\&M Univ., College Station.

Long, R.E., D. Price, R.D. Pieper, G.B. Donart, and J.D. Wallace. 1982. Comparison of cattle diets under continuous and short-duration grazing. Proc. West. Sec. Amer. Soc. Anim. Sci. 33:268-271.

de Moraes, E.A. 1985. Cattle diets from yearlong and rotational grazing at two stocking densities on the Texas Experimental Ranch. Ph.D. Diss., Texas A\&M Univ., College Station.

Pitts, J.S., and F.C. Bryant. 1987. Steer and vegetation response to short duration and continuous grazing. J. Range Manage. 40:386-389.

Pluhar, J.J., R.W. Knight, and R.K. Heitschmidt. 1987. Infiltration rates and sediment production as influenced by grazing systems in the Texas Rolling Plains. J. Range Manage. 40:240-243.

Ralphs, M.H., M.M. Kothmann, and L.B. Merrill. 1986. Cattle and sheep diets under short-duration grazing. J. Range Manage. 39:217-222.

Savory, A., and S.D. Parsons. 1980. The Savory grazing method. Rangelands 2:234-237.

Sharrow, S.H. 1983. Forage standing crop and animal diets under rotational vs. continuous grazing. J. Range Manage. 36:447-450.

Taylor, C.A., M.M. Kothmann, L.B. Merrill, and D. Elledge. 1980. Diet selection by cattle under high-intensity low-frequency, short-duration, and Merrill grazing systems. J. Range Manage. 33:428-434.

Van Soest, P.J., R.H. Wine, and L.A. Moore. 1987. Estimation of the true digestibility of forage by the in vitro digestion of cell walls. Proc. 10th Int. Grassl. Cong. 10:438-441.

Walker, J.W., and R.K. Heitschmidt. 1986. Effect of various grazing systems on type and density of cattle trails. J. Range Manage. 39:428-431.

Walker, J.W., R.K. Heitschmidt, and S.L. Dowhower. 1988. Cattle preference for plant communities in rotational and continuous grazing treatments. J. Range Manage. 42:143-148.

Walker, J.W., and E.W. Richardson. 1986. Replication in grazing studies: Why bother? p. 58-58. In: Proc. Statistical Analyses and Modeling of Grazing Systems Symp. C.D. Bonham, S.S. Coleman, C.E. Lewis, and G.W. Tanner eds.) Soc. Range Manage. Denver, Colo. 